\title{
PEACEFUL ENTRY: ENTREPRENEURSHIP DYNAMICS DURING COLOMBIA'S PEACE AGREEMENT
}

\author{
CAROLINA BERNAL ${ }^{\dagger}$, MOUNU PREM $^{\ddagger}$, JUAN F. VARGAS ${ }^{\star}$, AND MÓNICA ORTIZ*
}

\begin{abstract}
While there is a large literature on how conflict affects entrepreneurship and investment, little is known about how the end of a conflict affects businesses and firms' creation. The direction of the effect is not obvious as conflicts bequest poverty and inequality -reducing the returns of investment-and the territorial vacuum of power inherent to most post-conflict situations may trigger new violent cycles. Studying Colombia's recent peace agreement and using a difference-in-differences empirical strategy, we document that dynamics of entrepreneurship in traditionally violent areas closely mapped the politics that surrounded the peace agreement. When the agreement was imminent after a 5-decade conflict and violence had plummeted, local investors from all economic sectors established new firms and created jobs. Instead, when the agreement was rejected by a tiny vote margin in a referendum and the party that promoted this rejection raised to power, the rate of firms' creation rapidly reversed.
\end{abstract}

JEL CODES: D74, D22

KEYwords: Firm entry, Conflict, Peace agreement, Colombia

Date: February 23, 2022.

We thank Michele Di Maio and seminar participants at University of South Carolina, University of Nottingham, Deakin University, Universidad del Rosario, and Universidad de Antioquia for helpful comments and suggestions. Prem acknowledges IAST funding from the French National Research Agency (ANR) under the grant ANR-17EURE-0010 (Investissements d'Avenir program). Lina García, Julian Naranjo, and Andrés Rivera provided excellent research assistance.

${ }^{\dagger}$ Department of Economics, Universidad del Rosario. email: carolina.bernalmac@urosario.edu.co.

${ }^{\ddagger}$ Department of Economics, Universidad del Rosario. email: francisco.munoz@urosario.edu.co.

${ }^{\star}$ Department of Economics, Universidad del Rosario. email: juan.vargas@urosario.edu.co.

*Confecámaras. email: monicalo.ortiz@urosario.edu.co. 


\section{INTRODUCTION}

A large literature documents how violent conflict hinders economic activity by destroying physical capital and infrastructure, diverting resources away from productive activities, shattering human capital, and thwarting trust, social capital, and market efficiency. Indeed, the aggregate effects of conflict are substantial. For example, Collier (1999) estimates that civil war reduces the annual growth of GDP by 2.2 percent, and Rodrik (1999) argues social conflicts largely explain the instances of growth collapse observed since the 1970s. The NGO Institute for Economics $\&$ Peace reckons that the economic impact of violence in 2020 was U.S. $\$ 15$ trillion, equivalent to almost 12 percent of the global GDP and roughly $\$ 1,950$ per person. ${ }^{1}$ The effect of violent conflict on private entrepreneurship is especially daunting, as firm creation and performance are key determinants of sustained economic growth and productivity (Aghion et al., 2004). Conflict increases uncertainty and reduces investment (Pshisva and Suarez, 2006; Singh, 2013), distorts firms' inputs and output prices (Rozo, 2018), and ultimately affects firms' survival (Camacho and Rodriguez, 2013; Blumenstock et al., 2018).

The converse relationship, however, needs not to hold. As conflict exacerbates poverty, inequality, and social discord, it creates the seeds for its reoccurrence (Blomberg and Hess, 2002; Koubi and Böhmelt, 2014). Moreover, post-conflict is often shaped by a general lack of state capacity and scant institutional presence in the territory (Prem et al., 2022, 2020). This likely obstructs economic recovery. Thus, it is unclear whether or not the end of the conflict promotes entrepreneurship, and the empirical evidence is meager. In theory, the direction of the effect likely depends on the extent to which the end of the conflict reduces the uncertainty associated with wartime investment. This is precisely what we document in this paper.

We study the effect of the recent efforts to end the five-decade-long conflict in Colombia on firms' creation. In October 2012, the Colombian government started peace negotiations with the Revolutionary Armed Forces of Colombia (FARC from the Spanish acronym), the largest and oldest guerrilla organization of the Western Hemisphere. After normal ebbs and flows, the main milestone of the peace process came on December 20 of 2014, when FARC declared a permanent ceasefire as a way to signal internal cohesion and a credible commitment to lay down their weapons. The

${ }^{1}$ See https://www.economicsandpeace.org/wp-content/uploads/2021/06/GPI-2021-web.pdf (last accessed $01 / 13 / 2022)$. 
ceasefire was largely met until replaced, on August 29 of 2016, by the definitive bilateral ceasefire and, shortly afterward, by the peace agreement. President Juan Manuel Santos, who insisted on the negotiated termination of the 50-year old conflict, was awarded the Peace Nobel Prize in 2016. The peace agreement, however, was rejected in a low turnout national referendum by a $0.5 \%$ vote margin. Moreover, the political party who campaigned for the 'No' vote also won the 2018 presidential election, following a platform that promised to tear apart the peace agreement.

Using a difference-in-differences empirical strategy as well as detailed firm-level data, we find that the 2014 ceasefire triggered a 15 percent differential increase in the entry of new firms in municipalities formerly affected by FARC violence. However, we show that this effect was only short-lived. Consistent with the uncertainty introduced by the results of the referendum and the threat of right-wing political leaders to sink the agreement, we also find that after two years the excess firm creation experienced by war-affected areas was replaced by a smaller and insignificant 6 percent differential decrease.

Our findings are robust to a battery of tests, including the introduction of municipal and departmentyear fixed effects as well as controlling for differential trends parametrized by various pre-treatment controls. They are also unaffected by selecting the municipal controls with machine learning techniques to maximize their capacity to predict firm creation (Belloni et al., 2014) and their inclusion via inverse probability weighting (Abadie, 2005) or in a doubly-robust way (Sant'Anna and Zhao, 2020). The results are also unchanged by collapsing the pre and post-ceasefire periods to avoid serial correlation (Bertrand et al., 2004), to increasing the overlap between treated and control areas (Crump et al., 2009), to using different definitions of the treatment and the dependent variables, and to performing a permutation test that randomizes the treatments across municipalities to obtain a distribution-free probability that our main result is driven by pure chance.

In order to study the potential mechanisms that drive the post-ceasefire dynamics of entrepreneurship, we investigate heterogeneous effects by exploiting both firm-level and pre-ceasefire municipal characteristics. We find that the differential firm entry that followed the ceasefire took place across a wide range of economic sectors (agriculture, tourism, manufacture, retail, and construction), but its magnitude was larger for firms in agriculture and construction. We also find that the effect was driven by the dynamics of very small firms, which is consistent with the fact that treated municipalities are mostly rural. In spite of this, we document that the differential firm entry was 
concomitant with larger employment levels. Regarding municipal-level heterogeneous effects, we document that the scope of firm creation was larger in places in which the conflict was more intense, with larger population density, and closer to the main markets.

We also find that the effect was larger in areas that received more government transfers. Consistent with this potential mechanism, we also investigate the differential level of firms' entry in places that benefited from policies directly targeted at favoring post-conflict recovery. Particularly, we study the role of tax cuts targeted at the creation of firms and the implementation of community-driven development programs. Because these policies started after the agreement was signed, these heterogeneities are specific to the sub-period that starts in 2017. This is important since, as mentioned, the differential surge in firms' creation only took place, on average, in 2015 and 2016, and it was followed by a sharp reversion. Interestingly, we find that areas that benefited from such programs did experience a differential firm entry in the later period. This suggests that active government policies have the potential to offset, at least partially, the uncertainty generated by the political turmoil around the implementation of the peace agreement.

The contribution of this paper is multifaceted. First and foremost, there is very little research on how conflict termination affects firms' creation and performance. This paper starts filling this important research and policy gap. One notable exception is Guidolin and La Ferrara (2007), who incidentally suggest that the end of a conflict is not unambiguously good for firms. Indeed, the sudden end of the conflict in Angola, after the killing of UNITA leader Jonas Savimbi, decreased the stock returns of diamond firms. This is because the UNITA's territorial control in Angola implied high entry barriers, as firms dealt directly with the rebel leadership. The end of the conflict terminated such privilege. A recent paper that also studies Colombia's peace agreement but does not directly address its effects on firms' creation or performance is de Roux and Martinez (2020). Instead, the authors show that the signing of the final agreement differentially increased agricultural credit disbursements in areas exposed to FARC violence. Interestingly, and in contrast with our findings, agricultural credit was largely unchanged by FARC's permanent ceasefire, which was declared almost two years before the final agreement was reached.

Instead, most of the existing literature focuses on the effect of conflict on entrepreneurship. ${ }^{2}$ Collier

$\overline{{ }^{2} \text { Two thorough }}$ reviews include Blattman and Miguel (2010) and Brück et al. (2013). The latter introduces a special issue of the Journal of Conflict Resolution on entrepreneurship and conflict. 
and Duponchel (2013) show that the intensity of conflict is negatively associated with the size of firms in Sierra Leone, and Camacho and Rodriguez (2013) find that it increases the probability that relatively small and young firms shut down in Colombia. Also for that country, Rozo (2018) estimates that violence lowers the prices of both inputs and outputs of exposed firms. Since the drop in output prices is larger, firms are forced to adjust their production down or leave the market. The fact that conflict pushes some firms to exit, while others remain in business can increase the market share of the surviving firms. Indeed, Prete and Di Maio (2021) show that the relationship between conflict exposure and the firms' performance in Libya is convex for such firms. Amodio and Di Maio (2018) find that, in Palestine during the Second Intifada, conflict disrupted the supply of inputs, pushing exposed firms to substitute domestically produced materials for imported ones and reducing their output value. Utar (2020) documents that, in the context of the Mexican Drug War, urban violence reduced firms' output, product scope, employment, and capacity utilization. The fall in employment is driven by a drop in both labor demand (via output reduction) and labor supply (via death or disability). Moreover, the effect is larger for relatively small firms and for those intensive in female employment. Similar results are documented by Ksoll et al. (2021) for the case of Kenya, where electoral violence reduced exports primarily via workers' absence and especially for smaller firms. Klapper et al. (2013) show that conflict in Cote d'Ivoire reduced firms' total factor productivity, especially for establishment either owned by or employing foreigners. Finally, conflict also affects trade flows and exchange, both across firms and with external markets (Hjort, 2014; Korovkin and Makarin, 2021a,b).

A second contribution is our capacity to observe informal as well as formal economic activity. Our detailed firm-level data set records firms' creation based on a new business registry with the local chamber of commerce. Importantly, however, this does not imply formalization in terms of neither social security contributions, tax contributions, or compliance with sanitary regulations. Instead, registration in the local chamber of commerce provides firms with benefits such as training workshops in accounting and marketing, and participation in product-specific market fairs. In sharp contrast to most of the existing literature, this implies that our results are valid for both formal and informal entrepreneurial activity. ${ }^{3}$

\footnotetext{
${ }^{3}$ Previous research on Colombia, that explores the effect of violence on firms exit uses a different data set that is however more restricted in the type of firms it allows to study. Indeed, Camacho and Rodriguez (2013) is limited to industrial plants with more than ten employees or with a production of at least US\$ 50,000 (in 2005 dollars). Unfortunately, however, our data do not allow us to separate formality from informality, to explore heterogeneous
} 
Third, we contribute to the recent literature on the (positive and negative) effects of conflict termination, most of which has focused on the case of Colombia. For instance, Prem et al. (2021b) and Guerra-Cújar et al. (2022) document that the ceasefire improved educational outcomes and increased fertility rates in formerly FARC-affected areas and Prem et al. (2021a) and Perilla et al. (2021) find positive socio-economic effects of post-conflict landmine demining efforts, but Prem et al. (2020) show that it also increased large scale deforestation and Prem et al. (2022) suggest that it triggered selective violence targeted toward local community leaders in areas disputed by illegal armed groups other than FARC. For the case of Somalia, Shortland et al. (2013) find a significant peace dividend for low-income households that varied according to the intensity of the conflict. A similar heterogeneity is documented by Serneels and Verpoorten (2015) for the case of Rwanda, and the authors argue that this is because conflict intensity shapes the pace of postconflict recovery.

The remainder of the paper is organized as follows: Section 2 provides some details on Colombia's armed conflict and the peace negotiations; Section 3 describes the data sources and measurement; Section 4 discusses our empirical strategy to estimate the causal effect of the end of the conflict on firm entry; and Section 5 reports our main results and robustness tests, while Section 6 discuss the potential mechanisms behind our main results. Finally, Section 7 concludes.

\section{Context}

2.1. Colombia's civil war and the peace process. Colombia's civil conflict started with the foundation of left-wing guerrillas FARC and the National Liberation Army (ELN from the Spanish acronym) in the mid-1960s. Guerrillas claim to represent the rural poor and have fought for over 50 years with the stated aim of overthrowing the government. In order to finance the protracted war, both groups have been profiting from several forms of illegal activities localized within the Colombian territory (Richani, 1997). This implies that sub-national territorial dominance is an important intermediate objective of the armed groups, and the infliction of violence on both military and civilian targets is a means of achieving it.

The conflict was a Cold War proxy until the end of the 1980s but escalated during the 1990s, fueled by the guerrillas' involvement in illegal drug trafficking and the consolidation of anti-guerrilla 
right-wing paramilitary groups. In the mid-1990s, the paramilitaries effectively became a third force in the conflict, when splintered paramilitary armies colluded under the umbrella organization of the United Self-Defense Groups of Colombia (AUC by its Spanish acronym). The 5-decade long, three-sided Colombian conflict resulted in over 9 million people formally registered with the state as victims of the conflict. ${ }^{4}$

In October 2012, the Colombian government and FARC started peace negotiations in Cuba. While the constant ebb and flow characterized the four-year-long process, one of the most significant milestones was establishing a permanent ceasefire by FARC on December 20, 2014. As a result of the ceasefire, FARC withdrew their troops to more remote areas where military contact with government security forces and other armed groups was unlikely to occur. This explains why FARC's offensive activities dropped by $98 \%$ during this period (CERAC, 2016). The negotiations were completed in June 2016 and the final peace agreement was submitted for electoral approval through a referendum held on October 2, 2016. The agreement got rejected by a $0.5 \%$ vote margin in an election with a very low turnout. After some adjustments that incorporated the criticism of the 'No' campaigners, the agreement was endorsed by Congress in December 2016.

In 2018, amid a high political polarization inherited from the peace referendum, the party that promoted the "No" vote won the presidential election on a platform of substantially revising the agreement and halting its implementation. Consequentially, the structural reforms that the agreement vowed were either halted or significantly slowed down.

\section{DATA}

3.1. Firms. Our main outcome is the creation of new firms. This comes from the business demographics of a database called Unique Business and Social Registry (RUES from its Spanish acronym), which includes the country's Registry of Commerce. ${ }^{5}$ RUES is maintained by Confecámaras, the umbrella organization that coordinates Colombia's 57 local Chambers of Commerce. The Registry of Commerce includes the location of the firm's establishments, its legal representation and statutory audit, the firm's economic activity, some financial information, and the current

\footnotetext{
${ }^{4}$ Source: Victims' Registry, from the Unit for the Victims Assistance and Reparation (https://www . unidadvictimas . gov.co/en).

${ }^{5}$ RUES' business demographics variables strictly follow the Manual on Business Demography Statistics developed by the European Union and the OECD. This ensures a standardization of firm demographic events such as births or firm creation.
} 
state of the firm (whether active or canceled). Each new firm must register with its local Chamber of Commerce within one month of starting its commercial activity. Moreover, they must renew its registry during the first three months of each year. This legal obligation allows Confercámaras to engage in a longitudinal monitoring of all private firms. Importantly, registration does not entail that the firm must pay neither social security contributions nor taxes, and registered firms may or may not comply with sanitary regulations. This implies that not all registered firms are formal (according to various formalization definitions), and so we can capture both formal and informal economic activity. ${ }^{6}$

RUES encompasses a total of six systems that consolidate the information of the 57 local Chambers of Commerce. Five of them are managed by the Chambers of the largest five cities, but host the records of 292 municipalities (26\% of the country, holding $56 \%$ of the firms). The remaining system is directly maintained by Confecámaras and hosts the information of the rest of the country. Following the Manual on Business Demography Statistics, RUES records the movement of firms overtime. For example, if a firm cancelled its commercial registration to transfer its commercial address to the jurisdiction of another Chamber, both registries will appear in RUES with the same firm's unique ID. This avoids counting such transfers as firm creation. Similarly, a firm that stops its commercial activity for less than three years and then re-registers with a Chamber is registered with the old ID. Thus, it is not counted as a new firm. Finally, the firm creation statistic does not include entries due to statutory reforms such as mergers, break-ups, or split-off.

Therefore, a new firm in our data is a business that began its commercial activity for the first time in a given year, regardless of its size, economic activity, or whether it has any employee. Such a firm must register to the Registry of Commerce and obtain a unique ID. We had access to yearly RUES cross sections from 2011 to 2018. This defines our sample period. In order to identify the firm's location in our sample, we used the firm's most recent record. It is also worth mentioning

\footnotetext{
${ }^{6}$ In Colombia there are four formalization dimensions, and firms can (and often do) comply with a subset only: i) formalization of its creation (registering with the chamber of commerce); ii) formalization in inputs (e.g., paying social security for the firms' employees); iii) formalization in production and commerce (e.g. complying with sanitary regulations); and iv) fiscal formalization (paying taxes). See the "Business Formalization Policy" document of the National Council of Economic and Social Policy (CONPES from the Spanish acronym). CONPES Policy Document No. 3956, available in the original Spanish form

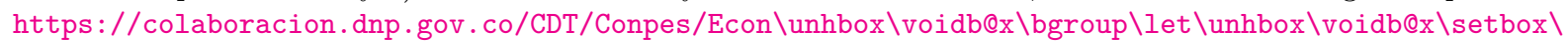

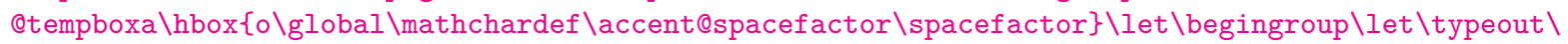

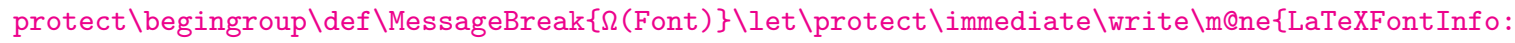

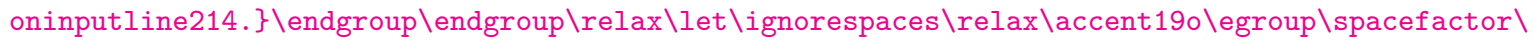
accent@spacefactormicos/3956.pdf (last accessed 01/14/2022).
} 
that, in addition to firm entry, we also use RUES to compute a range of additional variables that we use in the paper for robustness and to explore potential mechanisms. These include the firm's size, the economic sector of new firms, and various employment variables. We explain each of these additional measures in their respective paper section.

3.2. Conflict. To construct a measure of exposure to FARC violence prior to the start of the ceasefire, we use the conflict dataset originally compiled by Restrepo et al. (2004), and updated through 2014 by Universidad del Rosario. This dataset codes violent events recorded in the Noche y Niebla reports from the NGO Centro de Investigación y Educación Popular (CINEP) of the Company of Jesus in Colombia, which provides a detailed description of the violent event, its date of occurrence, the municipality in which it took place, the identity of the perpetrator, and the count of the victims involved in the incident. ${ }^{7}$

We first created a discrete variable that measures the extensive margin of FARC violence. This variable takes the value one if there was at least one FARC attack from 2011 to 2014 in a municipality. This is the period elapsed after president Juan Manuel Santos took office and before the beginning of the permanent ceasefire. We also present results using two variants of this definition. The first one is a continuous measure based on the total number of FARC attacks over 10,000 inhabitants that took place from 2011 to 2014 in a municipality. The second is a discrete measure that identifies municipalities' highly exposed to FARC violence. To compute the latter we defined a dummy that takes the value of one for places above the bottom quartile of the continuous measure, thus not including municipalities with few events relative to their population. Finally, we created another measure of conflict intensity by defining a dummy that takes the value of one for municipalities that experienced in 2014 FARC attacks above the median.

3.3. Descriptive statistics. Table 1 reports descriptive statistics of our main variables and exposure measures during the period 2011-2014. On average there are 83 new firms entering a municipality every year, with a large standard deviation of 191, which is consistent with the large heterogeneity of the country's municipalities and in terms of economic activity. In turn, $9 \%$ of the municipalities experienced at least one attack by FARC in the period 2011 to 2014.

\footnotetext{
${ }^{7}$ Noche y Niebla sources include "1. Press articles from more than 20 daily newspapers of both national and regional coverage. 2. Reports gathered directly by members of human rights NGOs and other organizations on the ground such as local public ombudsmen and, particularly, the clergy." (Restrepo et al. 2004, p. 404). Notably, since the Catholic Church is present in even the most remote areas of Colombia, we have extensive coverage of violent events across the entire country.
} 
Table A.1 in the Appendix presents the average of the characteristics during the period 2011-2014 for municipalities non-exposed to FARC violence and the difference between municipalities exposed and not exposed. FARC exposed municipalities have, on average, a larger number of firms entering the market, a higher population, a higher share of the rural population, a higher poverty index, and are further away from the department's capital. ${ }^{8}$

\section{EMPiRicAl STRATEGY}

4.1. Main specification. Our identification strategy exploits the timing of the permanent ceasefire announced by FARC on December 20, 2014, as well as the spatial distribution of the exposure to FARC violence across municipalities prior to the ceasefire. More formally, using the sub index $m$ to denote municipalities, $d$ to denote departments, and $t$ to denote time, we estimate the following difference-in-differences regression model:

$$
y_{m d t}=\alpha_{m}+\lambda_{d t}+\beta\left(\text { Cease }_{t} \times F A R C_{m}\right)+\sum_{c \in \mathbf{X}_{\mathbf{m}}} \gamma^{\prime}\left(c \times \text { Cease }_{t}\right)+\varepsilon_{m d t}
$$

where $y_{m d t}$ is our measure of firm creationin the baseline specification, or any of the additional outcomes we study to understand the potential mechanisms. $F A R C_{m}$ measures pre-ceasefire exposure to FARC violence in municipality $m$, and Cease $e$ is a dummy that takes the value one after the start of the permanent ceasefire. $\alpha_{m}$ are municipality fixed effects and $\lambda_{d t}$ are departmentceasefire fixed effects. These control, respectively, for any observed or unobserved municipal-level time invariant heterogeneity and for any shock that affects simultaneously all the municipalities of the same department. $X_{m}$ are municipality characteristics measured before the ceasefire that we interact with the time indicator that identifies the ceasefire period to flexibly control for differential changes pre- and post-ceasefire, parametrized by each one of the municipal attributes. ${ }^{9}$ Finally, $\varepsilon_{m d t}$ is the error term, which we cluster at the municipality level. As a robustness, we estimate p-values using a variance-covariance matrix that takes into account cross-sectional dependence in the error term following Conley (1999) and Conley (2016).

Our coefficient of interest, $\beta$, captures the differential change before and after the ceasefire in firm entry in municipalities exposed to FARC violence versus those that were not exposed to FARC

${ }^{8}$ The information on municipal characteristics comes from an annual panel of Colombian municipalities, constructed by the Center of studies on Economic Development (CEDE by the Spanish acronym), a think-tank at Universidad de los Andes.

${ }^{9}$ The set of characteristics includes the logarithm of population, the share of rural population, a poverty index, and the log distance to the department capital. 
violence. We also estimate a variant of equation (4.1) where we split the ceasefire period into two, based on the peace agreement plebiscite that took place at the end of 2016. In that specification, the coefficient $\beta$ of equation (4.1) becomes $\beta_{1}$ for the years 2015 and 2016, and $\beta_{2}$ for the years 2017 and 2018. 2018 is the end of our sample period due to data limitations (see section 3.1).

4.2. Identifying assumption. The main assumption behind our difference-in-differences model is that, in the absence of the ceasefire, firm creation in municipalities exposed to FARC violence would have evolved similarly to firm creation in non-exposed municipalities. The validity of this "parallel trends" assumption can be partially assessed by estimating the following equation:

$$
y_{m d t}=\alpha_{m}+\lambda_{d t}+\sum_{j \in T} \beta_{j}\left(F A R C_{m} \times \delta_{j}\right)+\sum_{c \in \mathbf{X}_{\mathbf{m}}} \gamma^{\prime}\left(c \times \text { Cease }_{t}\right)+\epsilon_{m d t}
$$

where $\delta_{j}$ are year dummies and $T$ includes all years in our sample except from 2014, which is the year before the ceasefire. Therefore, the parameters $\beta_{j}$ can be interpreted as the difference in firm creation in municipalities exposed to FARC violence and municipalities non-exposed, in year $j$ relative to the year at the end of which the ceasefire started.

4.3. Potential mechanisms. We can use variation across municipal-level characteristics to estimate heterogeneous effects that may shed light one the underlying mechanisms of the effect of the ceasefire on firm creation. To that end, we augment the main specification (equation 4.1) by adding a third interaction term. Specifically, let the municipal characteristic $Z_{m}$ (measured before the ceasefire) be a potential mechanism of interest. We then estimate:

$$
\begin{aligned}
y_{m d t} & =\alpha_{m}+\delta_{d t}+\tau_{1}\left(\text { Cease }_{t} \times F A R C_{m} \times Z_{m}\right)+\tau_{2}\left(\text { Cease }_{t} \times Z_{m}\right)+\tau_{3}\left(\text { FARC }_{m} \times Z_{m}\right) \\
& +\beta_{4}\left(\text { FARC }_{m} \times \text { Cease }_{t}\right)+\sum_{c \in \mathbf{X}_{\mathbf{m}}} \gamma^{\prime}\left(c \times \text { Cease }_{t}\right)+\mu_{m d t}
\end{aligned}
$$

Our coefficient of interest, $\tau_{1}$, captures the differential change in firm creation in places exposed to FARC violence in municipalities with characteristic $Z_{m}$. The set of characteristics, $Z_{m}$, includes a pre-ceasefire conflict intensity indicator, the average transfers received by the municipality fro, a higher government level, population density, and the distance to the main near markets. Note that the results coming from this test are suggestive about potential mechanisms, but not necessarily causal. They have to be interpreted with caution.

Using the above specifications we estimate the impact of the December 2014 permanent ceasefire on firm entry in areas previously exposed to FARC violence (equation 4.1), the differential pre-trends 
and dynamic persistence of this effect (equation 4.2), and key heterogeneous effects (equation 4.3). The next section reports the estimated results and robustness tests.

\section{Results}

5.1. Main results. Table 2 reports the coefficients resulting from estimating equation (4.1) using firms entry as the dependent variable. In columns 1 to 3, we bundle the ceasefire period from 2015 to 2018. Instead, columns 4 to 6 split the ceasefire between the periods 2015-2016 and 2017-2018. Municipality fixed effects are included in all specifications. Columns 1 and 4 include year fixed effects and no controls, columns 2 and 5 include department $\times$ ceasefire fixed effects and no controls, and columns 3 and 6 include the latter but also control for post-ceasefire differential changes in firm entry parametrized by several pre-ceasefire municipality characteristics (as discussed in Section 4.1). The standard errors in parentheses are clustered at the municipality level, while square brackets report the p-values for standard errors that allow for spatial and first-order time correlation (see Conley, 1999, Conley, 2016). In addition, in columns 4 to 6 we present the p-values of a test of the difference in the coefficients associated with the interaction between FARC and years 2015-2016, and the interaction between FARC and years 2017-2018.

The first three columns suggest that there is a positive but not a significant increase in firms' creation in places traditionally affected by FARC violence, after the start of the ceasefire. The magnitude of the differential increase in firm creation is 2.3 percent. ${ }^{10}$ However, this effect masks a large heterogeneity between the early and later years after the start of the ceasefire. According to our preferred specification, reported in column 6 , we find that, over the first two years, the ceasefire triggered a 15 percent differential increase in firms' creation in FARC-affected areas. Instead, starting in 2017, this trend reverses and we find an insignificant -5.8 percent differential decrease in the entry of new firms in such areas. Moreover, the difference between these coefficients is highly significant, with p-values $<1 \%$.

We interpret this heterogeneity as consistent with the positive expectations and optimism that an approaching peace agreement generated in municipalities traditionally exposed to FARC violence. The expected peace differences, that were immediately manifest in a large improvement in the educational outcomes of these places (Prem et al., 2021b), attracted new investors. In accordance

\footnotetext{
${ }^{10}$ As suggested by Bellemare and Wichman (2020), we compute the percentage change in the outcomes subject to a
} hyperbolic sine transformation (such as firms' entry) as $e^{\hat{\beta}}-1$. 
with this interpretation, the fiasco of the rejected peace referendum in October 2016 and the uncertainty that was concomitant to the empowerment of the political losers of the peace agreement (Fergusson, 2019) led to a differential decrease in firms' entry in the later years.

Unfortunately, RUES does not allow us to exploring whether the dynamics of the differential firm entry in FARC-exposed municipalities after the start of the ceasefire have a firm exit counterpart. This is because of changes in the legislation that led to inconsistencies in how the Registry of Commerce computes the volume of firms that shut down. Indeed, Law 1727 of 2014 determined that firms that have failed to comply with the obligation of renewing their commercial registration for five consecutive years must be dissolved, cancelling the record altogether. Clearly, this reform artificially increased the volume of firms that exit the market precisely after the start of the ceasefire in 2015. Looking at firm exit with the available measure would therefore yield upward biased estimates. $^{11}$

5.2. Identifying assumption. In order to partially validate the parallel trends assumption and to study the temporal dynamics of firms' creation after the start of the ceasefire, we estimate equation 4.2. The estimated coefficients are plotted in Figure 1. Panel A presents the results for the main specification with municipality and year fixed effects; Panel B focuses on the specification that includes department $\times$ ceasefire fixed effects; and Panel on the one that adds pre-ceasefire controls interacted with the ceasefire dummy. In all cases, we find no differential change in entry of new firms in municipalities exposed to FARC violence before the ceasefire, with the estimated coefficients moving around zero. This points to the absence of differential pre-trends in firm creation and thus provides support for the use of a difference-in-differences empirical strategy. In addition, the figures also reveal visual evidence consistent with the reported time heterogeneity in the differential formation of new businesses following the ceasefire, with a large differential increase in treated municipalities in 2015 and 2016 and a reversion thereafter.

We also conduct a more parametric test for the existence of differential trends during the preceasefire period (2011-2014), in the spirit of Muralidharan and Prakash (2017). Specifically, we interact a linear trend with our measure of exposure to FARC violence and test for the significance

\footnotetext{
${ }^{11}$ Regrettably, with the pre-processed data set we obtained from Confecámaras we could not separate firm cancellations due to the enforcement of this law from actual business closures.
} 
of this coefficient prior to the ceasefire. ${ }^{12}$ The results are reported in column 1 of Table 3 and point to the lack of differential trends in the rate of firms' creation before the ceasefire.

Finally, we also perform a placebo exercise using the date on which the government and FARC achieved the first important milestone of the peace process. On May 26, 2013, the parties reached an agreement on the first point of the peace negotiation agenda, namely the need for a comprehensive rural reform including regulating land use and access, discouraging unproductive land, improving land property titles, investing in rural infrastructure, and providing technical assistance and subsidies to improve agricultural production. This was the first out of six partial agreements reached prior to signing the final peace accord in September 2016.

The regressions for this exercise follow the structure of equation (4.1) but, instead of a Cease time indicator, we include a Placebo Cease one, which takes the value of one for the years 2013 and 2014, and another that takes value one for the years 2012 to 2014. For this analysis, we focus on the sample period between 2011 and 2014, so as to capture potential pre-ceasefire trends. We find that there is no differential change in firm entry in areas exposed to FARC violence relative to FARC-free areas after this agreement was reached (see Table 3 column 2 and 3). These results are consistent with the absence of differential pre-ceasefire trends and provide credibility to our main finding, namely that the differential evolution of firm creation between these two types of municipalities is driven by the ceasefire.

5.3. Further robustness. We now assess the robustness of our main findings to a series of empirical exercises that we present in this subsection.

5.3.1. Municipality covariates. We begin by augmenting our most demanding specification by adding a larger list of potential municipality characteristics. To that end, we follow Belloni et al. (2014) and select the set of pre-ceasefire municipality characteristics using machine learning. Column 4 of Table 3 shows that the results are robust to this exercise.

5.3.2. Standard errors. To assess the robustness of our standard errors, we follow Bertrand et al. (2004) and collapse our data before the ceasefire, during early years after the start of the ceasefire,

\footnotetext{
${ }^{12}$ The specification we run is $y_{m d t}=\alpha_{m}+\lambda_{d t}+\beta\left(F A R C_{m} \times\right.$ Trend $\left._{t}\right)+\epsilon_{m d t}$, where Trend $d_{t}$ is a linear trend and we restrict the sample to the years 2011 to 2014. Our parameter of interest, $\beta$, captures whether there are differential trends between municipalities exposed and not exposed to FARC.
} 
and over the later years. We do so to deal with potential serial correlation. Column 5 of Table 3 shows that our results are also robust to this practice.

5.3.3. Comparison municipalities. One threat to our identification is that municipalities exposed to FARC violence are different to areas not exposed and that in 2014 there was some "shock" (other than the ceasefire) that differentially affected these municipalities because of such characteristics but not because of the prior exposure to FARC violence. To alleviate this concern, we estimate our main model using a different set of control municipalities, which we select following Crump et al. (2009). Based on an estimated propensity score, we truncate the sample in order to increase the overlap of treated and control municipalities in terms of various municipality characteristics. ${ }^{13} \mathrm{We}$ perform this truncation using the optimal cut-off suggested by Crump et al. (2009), which in our case is $4.3 \%$. Column 6 of Table 3 shows that our results are also robust to this sample truncation strategy.

In addition, we estimate a version of the treatment effects weighting by a propensity score of the probability of being exposed to FARC violence. First, we follow Abadie (2005) and use an inverse probability weighting for our difference-in-differences estimator, which considers that there may be differences in observed characteristics between treated and control municipalities. Then, we follow Sant'Anna and Zhao (2020) and estimate a doubly-robust version of our estimate that is robust to either a misspecification of the propensity score used for weighting or a misspecification of the linear model. Again, we find effects of similar magnitudes and significance (see Columns 7 and 8 of Table 3).

5.3.4. Measurement of the dependent variable. We now check whether our results are robust to different ways of measuring our outcome variable. First, instead of using the hyperbolic transformation, which helps us to deal with cases when in a municipality-year level there was no firms' creation, we use the logarithm of firm entry plus one. Second, instead of using a logarithmic transformation, we use the number of entrants as our dependent variable. Columns 9 and 10 of Table 3 show that our results are robust to the way we define our dependent variable.

5.3.5. Measurement of exposure to FARC violence. Columns 11 and 12, instead, report the robustness of our baseline results to using two alternative measures of exposure to FARC violence.

\footnotetext{
13 The set of potential controls includes the logarithm of population, the distance to department capital, the share of rural population, and a poverty index.
} 
The first one (column 11) is a continuous measure of conflict based on the total number FARC attacks between 2011 and 2014 over the municipal population. For interpretation, this measure is standardized. The second (column 12) is a more stringent measure of "high exposure" to FARC violence. It is an indicator that takes the value of one for municipalities above the bottom quartile of the empirical distribution of the per capita FARC attacks, conditional on experiencing at least one attack. In column 11, we find that a one standard deviation in FARC violence per capita increases firms' entry by 5.5 percent, while in column 12, we find a similar but somewhat larger effect in municipalities with high exposure to FARC violence prior to the start of the ceasefire.

5.3.6. Randomization inference. We also conduct a permutation test by randomly assigning the FARC exposure indicator across municipalities over 200 times, with the random assignment being consistent with the observed distribution of municipalities exposed to FARC violence. This provides us with a distribution-free estimate of the probability that our coefficient of interest arises by chance. Reassuringly, our estimated coefficient (red vertical line) is above the 99th percentile of the resulting distributions of the effect of the ceasefire on firms' entry during the early post-ceasefire period (Panel A of Appendix Figure A.2).

5.3.7. Influential geographical units. Finally, we check whether our findings are driven by a particular treated municipality or by one specific department. ${ }^{14}$ Appendix Figure A.1 presents the robustness of our results to both of these tests. By and large, all coefficients remain stable and statistically significant.

\section{Mechanisms}

In this section, we explore the empirical relevance of several potential mechanisms through which the absence of violent conflict promotes new investments in markets previously affected by conflict violence. In particular, we explore key heterogeneity according to firm characteristics such as the size and economic sector, and to municipal attributes related to active post-conflict policies, the connectivity of markets, government transfers, and potential agglomeration economies.

6.1. Firm size. RUES classifies firms across different sizes, from micro firms, to small, medium, and large firms. This is done according to the firm's assets value and number of employees, both self-reported in the firm's yearly registration (first year) or renewal (thereafter) form, submitted to

\footnotetext{
${ }^{14}$ Colombia has 32 departments, equivalent to US states.
} 
the local Chamber of Commerce. ${ }^{15}$ Micro firms are those that report total assets of less than 500 legal monthly minimum wages (LMMW), or else less than 10 employees. Small firms are those that report total assets between 501 and 5,000 LMMW, or else between 11 and 50 employees. Mediumsized firms report between 51 and 200 workers; and the remaining firms are classified as "large."

Table 4 re-estimates the baseline specification for the different subsamples of firms according to their size. We find that our results are driven by micro-businesses, the smallest firms. During the first two years following the ceasefire, the number of micro-firms differentially grew in 15 percent in FARC-affected areas (column 2). This is consistent with the new investments taking place in mainly rural and peripheral areas (where FARC was mostly active). According to the MicroBusiness survey conducted by the National Statistics Bureau in 2019, micro firms can develop their economic activity in any location (e.g. home, premises, door to door, etc.). This suggests that the new firms that are entering the market after the start of the ceasefire are being constituted by settlers of the same municipalities previously affected by FARC's violence. Once the group's offensive activity plummeted, they likely saw the opportunity to undertake new activities. These investors, moreover, come from small and relatively poor peripheral areas, and thus the large majority is unlikely to create larger size firms. ${ }^{16}$ However, the dynamics of micro-firms could also be partly explained by the fact that assets and employment are self-reported, and even if the Chambers of Commerce are not a tax authority, firm owners may likely tend to under-report. For instance, the price that firms must pay to register is proportional to their size. Consistently, the reported assets value bunches at $\operatorname{COP} \$ 1 .{ }^{17}$

We also find a statistically significant albeit very small (2 percent) increase in the number of medium-sized firms in the post-referendum period (column 6). The results from estimating the dynamic specifications of the differential firm creation in FARC-affected municipalities before and after the ceasefire by size is reported in Figure 2. By and large, these dynamics map the results reported in Table 4.

\footnotetext{
${ }^{15}$ This classification follows the ruling of Law 905 of 2004 . Its original in Spanish can be accessed here: http: //www.secretariasenado.gov.co/senado/basedoc/ley_0905_2004.html (last accessed 01/15/2022).

${ }^{16}$ According to Colombia's National Household Budget Survey, the PPD-adjusted average monthly income of Colombian household in 2016-2017 was COP\$1,773,262 (US\$1,335 in 2017 prices).

${ }^{17}$ For this same reason, we do not explore assets' value as a dependent variable. Instead, for the case of employment RUES includes both the self-reported number of workers and that available from the employer-employee administrative data set. We look at the effect of the ceasefire on the employment of new firms below.
} 
6.2. Employment. We also look at the effect of the ceasefire on the number of employees of the newly created firms. To this end, we look at two different employment measures. The first is the number of employees that the firm reports on the registry (Panel A of Table 5). This measure has advantages and disadvantages: On the one hand, it may include informal employment (which is not registered in the social security system). On the other it is self-reported. The second measure comes from merging RUES with the employer-employee administrative data set, called Planilla Integrada de Liquidación de Aportes (PILA). As such, PILA only picks up formal employment, for which social security contributions are made (Panel B).

In both cases, we find that the employment of new firms differentially rose in FARC-affected areas. That is new businesses in violence-recovering areas employed more workers than new businesses in other places. While self-reported employment only did so in the early post-ceasefire period (Panel A, columns 4 to 6), formal employment rose over the entire post-ceasefire period (Panel B, columns 4 to 6 ). This discrepancy is consistent with a potential lag in the desire of the new firms to formalize their workers, which is consistent with an initial uncertainty about the firm's survival.

The results from estimating the dynamic specifications of the differential employment in newly created firms in FARC-affected municipalities before and after the ceasefire is reported in Figure 3.

6.3. Economic sectors. We also explore potential heterogeneity according to the economic sector of the new investments. Table 6 suggests that the entry of new firms takes place across a wide range of economic activities. Specifically, column 2 suggests that there is a 17 percent differential increase in entrepreneurship in the agriculture during the first two years following the ceasefire. This result is in line with the increase in deforestation in areas previously affected by FARC after the ceasefire found by Prem et al. (2020). In addition, column 4 shows that investments in tourism differentially rose by 12 percent over the same period (as did the investment in the retail sector -column 8). This is consistent with the higher willingness to pay by foreigners to visit these remote and now safer areas for touristic reasons such as bird-watching (Maldonado et al., 2018). Finally, columns 6 and 10 imply that the creation of firms is not specific for low value-added sectors, which are also easier to develop in rural areas. Indeed, we also find an increase in entrepreneurship in sectors that entail expectations of high economic growth, such as construction and manufacturing. Firms in these sectors differentially increased by 14 percent in FARC-affected areas during 2015 and 2016 . 
The effect over the later post-ceasefire period, after the victory of the 'No' vote in the plebiscite, is not statistically significant for neither of the economic sectors. Moreover, the coefficients are much smaller and of changing signs depending on the sector.

The results from estimating the dynamic specifications of the differential firm entry by economic sector, in newly created firms in FARC-affected municipalities before and after the ceasefire, is reported in Figure 4.

\subsection{Heterogeneity by municipality characteristics.}

6.4.1. Post-conflict recovery programs. In the decree 1650 of 2017, the Ministry of Finance, the National Planning Department, and the Territory Renewal Agency identified 344 municipalities (about a third of the country) as the Most Affected Areas by the Armed Conflict (ZOMAC from its Spanish acronym). The selection used indicators of conflict exposure, institutional weakness, multidimensional poverty, and rurality. ${ }^{18}$ The government offered tax benefits for ten years to companies that developed their entire production process in these areas and complied with minimum investment and job creation levels.

An additional post-conflict reconstruction program, called Development Programs with a Territorial Approach (PDET) were created by Decree 893 of 2017. Effectively, the PDET are community development programs targeted at rural areas affected by the conflict and featuring illicit economies. ${ }^{19}$ They are planned to last for 10 years and their objective is to provide institutional and financial support to the targeted communities to help them design and implement comprehensive rural reform programs, aimed at the transformation of the rural sector and focusing on areas such as rural property, infrastructure, and land use; agricultural production; rural education, housing and basic services; food security; reconciliation and peace; and environmental sustainability.

Within our sample, 176 municipalities received ZOMAC but not PDET, one benefited from PDET but not ZOMAC, and 166 obtained both. Moreover, only 90 of the 344 ZOMAC municipalities belong to our baseline definition of FARC exposure, and 11 treated municipalities are not in the ZOMAC group. Also, 71 PDET municipalities belong to our treatment, and 31 treated municipalities are not part of PDET. This gives us plenty of variation to estimate heterogeneous effects by

\footnotetext{
${ }^{18}$ The methodology used for the selection of these areas is explained in: https://www.dnp.gov.co/Paginas/ Beneficios-tributarios-para-empresas-que-inviertan-en-344-municipios-afectados-por-el-conflicto. aspx (last accessed 01/15/2022).

${ }^{19} \mathrm{~A}$ total of 170 municipalities in 19 departments were selected to as part of this program.
} 
the presence of the two flagship post-conflict recovery programs of the Colombian government.

Table 7 reports these heterogeneity. Columns 2 and 4 include a dummy that takes the value of one if the municipality benefits from one of the programs (ZOMAC and PDET respectively). We are interested in the triple interaction of this indicator with the FARC-exposure dummy and the late ceasefire period (years 2017 and 2018). Since the policies stared in 2017, we cannot explore this heterogeneity for the early ceasefire period (2015-2016). We find a significant differential increase in firms' entry in FARC-exposed municipalities that benefited from either of these policies during the later post-ceasefire period. The effect is also larger in magnitude for these municipalities than the average effect on FARC-exposed municipalities over the same years, and it has the opposite sign. This suggests that during the period of greater disappointment and uncertainty around the future of the peace process, investors in formerly FARC-affected areas decided to enter the market only in municipalities that benefited from tax cuts and community-driven comprehensive rural reforms. Put it differently, active government post-conflict development policies were able to offset the negative effect that the peace fiasco has on entrepreneurship.

6.4.2. Other municipality characteristics. In addition to government policies, a range of municipal characteristics may likely shape the magnitude and direction of the effect of the ceasefire on firms' creation. In Table 8 we explore four such potential exacerbating factors: i) the pre-ceasefire intensity of the conflict, ii) the transfers received from the government, iii) population density, and iv) the distance to markets. In particular, we expected, the baseline effect to be larger, respectively, in i) areas traditionally more affected by the conflict and thus likely to catch-up faster after violence plummets, ii) places where more resources are available and potentially where public investment is higher, iii) areas with greater potential to develop agglomeration economies, and iv) places more connected to labor, input, and product markets.

Column 1 of Table 8 adds to the baseline specification the triple interaction with an indicator of whether a municipality experienced FARC violence above the median of the empirical distribution in 2014, the last year before the start of the ceasefire. We find a differential increase in firm's entry both in the early and the late post-ceasefire years. This suggests that the post-referendum investment dismay was offset by the potential economic catch-up of municipalities heavily affected by conflict. Column 2 studies the triple interaction with a standardized measure of the resources transferred to the municipality by another level of the government (the department or the central 
government). In line with the findings by Camacho and Rodriguez (2013), we show that the increase in business' entry during the early ceasefire period (2015-2016) is exacerbated in 6 percent in municipalities that received one standard deviation higher transfers than the average. Column 3 looks at the triple interaction with areas with a population density above the lower quartile (measured in 2014, before the ceasefire). We find that the increase in firms' entry during the early ceasefire period is exacerbated by 15 percent in relatively denser municipalities. This suggests that the expected returns of micro businesses are potentially larger in areas with a higher potential demand, or with relatively more availability of workers. Relatedly, in column 4, we find that towns that are further away from the main food markets experience a much lower differential increase in the creation of firms in the two years following the start of the ceasefire. This implies that more isolated and remote markets are less profitable and thus less attractive to investors.

\section{Conclusion}

While the literature on how conflict affects entrepreneurship and private investment is vigorous and has identified a number of potential mechanisms that mediate such a relationship, we know comparatively very little about how the end of a conflict affects businesses. A priory, the direction of the effect is not obvious, as conflicts bequests poverty traps and inequality that reduce the returns of investment, and the territorial vacuum of power that is inherent to most post-conflict situations likely invites future violent disputes and confrontation. This paper starts filling this gap by studying the recent experience of Colombia, and particularly the colossal reduction in violence that FARC strongholds suddenly experienced after this insurgent group declared a credible and permanent ceasefire at the end of 2014, amid peace negotiations with the Colombian government.

Our findings suggest that the dynamics of entrepreneurship in traditional FARC-exposed areas closely mapped the politics that surrounded the peace agreement. When the agreement was imminent and the 5-decade conflict was ending, and FARC had stopped using violent means, local investors from all economic sectors established new, albeit small businesses and created more jobs, especially in the agricultural sector and in denser areas that are located closer to markets. Instead, when the agreement was rejected by a tiny vote margin in a referendum and the right-wing party that promoted this rejection raised to power, the investors' hubris reversed.

Importantly, we find that there is room for hope. Particularly, the post-referendum investors' 
disappointment was partially offset by active government recovery policies aimed at promoting local economic activity and community-driven rural development. Our findings imply that the implementation of the peace agreement should be taken seriously, and should not be politicized. 


\section{REFERENCES}

Abadie, A. (2005): "Semiparametric difference-in-differences estimators," The Review of Economic Studies, 72, 1-19.

Aghion, P., R. Blundell, R. Griffith, P. Howitt, and S. Prantl (2004): "Entry and productivity growth: Evidence from microlevel panel data," Journal of the European Economic Association, 2, 265-276.

Amodio, F. And M. Di Maio (2018): "Making do with what you have: Conflict, input misallocation and firm performance," The Economic Journal, 128, 2559-2612.

Bellemare, M. F. And C. J. Wichman (2020): "Elasticities and the inverse hyperbolic sine transformation," Oxford Bulletin of Economics and Statistics, 82, 50-61.

Belloni, A., V. Chernozhukov, and C. Hansen (2014): "High-dimensional methods and inference on structural and treatment effects," Journal of Economic Perspectives, 28, 29-50.

Bertrand, M., E. Duflo, and S. Mullainathan (2004): "How much should we trust differences-in-differences estimates?" The Quarterly Journal of Economics, 119, 249-275.

Blattman, C. And E. Miguel (2010): "Civil war," Journal of Economic literature, 48, 3-57.

Blomberg, S. B. And G. D. Hess (2002): "The temporal links between conflict and economic activity," The Journal of Conflict Resolution, 46, 74-90.

Blumenstock, J. E., T. Ghani, S. R. Herskowitz, E. Kapstein, T. Scherer, and O. Tоомет (2018): "Insecurity and industrial organization: Evidence from Afghanistan," World Bank Policy Research Working Paper.

Brück, T., W. Naudé, and P. Verwimp (2013): "Business under fire: Entrepreneurship and violent conflict in developing countries," Journal of Conflict Resolution, 57, 3-19.

Camacho, A. And C. Rodriguez (2013): "Firm Exit and Armed Conflict in Colombia," Journal of Conflict Resolution, 57, 89-116.

CERAC (2016): "Un año de desescalamiento: conflicto casi detenido, pero que se resiste a desaparecer," Monitor de Desescalamiento del Conflicto Armado Interno en Colombia, 12.

Collier, P. (1999): "On the economic consequences of civil war," Oxford Economic Papers, 51, $168-183$.

Collier, P. And M. Duponchel (2013): "The economic legacy of civil war: Firm-level evidence from Sierra Leone," The Journal of Conflict Resolution, 57, 65-88. 
Conley, T. G. (1999): "GMM estimation with cross sectional dependence," Journal of Econometrics, 92, 1-45.

(2016): Spatial Econometrics, London: Palgrave Macmillan UK, 1-9.

Crump, R. K., V. J. Hotz, G. W. Imbens, and O. A. Mitnik (2009): "Dealing with limited overlap in estimation of average treatment effects," Biometrika, 96, 187-199.

De Roux, N. And L. R. Martinez (2020): "Conflict reduces investment: Evidence from the demand for agricultural credit in Colombia," Available at SSRN.

Fergusson, L. (2019): "Who wants violence? The political economy of conflict and state building in Colombia," Cuadernos de Economía, 38, 671-700.

Guerra-Cújar, M. E., M. Prem, P. A. Rodríguez-Lesmes, and J. F. Vargas (2022): “A Peace Baby Boom? Evidence from Colombia's Peace Agreement," .

Guidolin, M. And E. La Ferrara (2007): "Diamonds are forever, wars are not: Is conflict bad for private firms?" American Economic Review, 97, 1978-1993.

HJorT, J. (2014): "Ethnic divisions and production in firms," The Quarterly Journal of Economics, 129, 1899-1946.

Klapper, L. F., C. Richmond, and T. T. Tran (2013): "Civil conflict and firm performance: Evidence from Cote d'Ivoire," World Bank Policy Research Working Paper.

Korovkin, V. And A. Makarin (2021a): "Conflict and inter-group trade: Evidence from the 2014 Russia-Ukraine crisis," Available at SSRN 3397276.

- (2021b): "Production Networks and War," Available at SSRN.

Koubi, V. And T. Böhmelt (2014): "Grievances, economic wealth, and civil conflict," Journal of Peace Research, 51, 19-33.

Ksoll, C., R. Macchiavello, and A. Morjaria (2021): "Guns and roses: Flower exports and electoral violence in Kenya," The Review of Economics and Statistics.

Maldonado, J. H., R. del Pilar Moreno-Sánchez, S. Espinoza, A. Bruner, N. Garzón, And J. Myers (2018): "Peace is much more than doves: The economic benefits of bird-based tourism as a result of the peace treaty in Colombia," World Development, 106, 78-86.

Muralidharan, K. And N. Prakash (2017): "Cycling to school: Increasing secondary school enrollment for girls in India," American Economic Journal: Applied Economics, 9, 321-50.

Perilla, S., M. Prem, M. E. Purroy, and J. F. Vargas (2021): "How Peace Saves Lives? Evidence from Colombia," . 
Prem, M., M. E. Purroy, and J. F. Vargas (2021a): "Landmines: The local effects of demining," Available at SSRN 3924929.

Prem, M., A. Rivera, D. Romero, and J. F. Vargas (2022): "Selective civilian targeting: The unintended consequences of partial peace," Quarterly Journal of Political Science.

Prem, M., S. SaAvedra, and J. F. Vargas (2020): "End-of-conflict deforestation: Evidence from Colombia's peace agreement," World Development, 129, 104852.

Prem, M., J. F. Vargas, and O. NAmen (2021b): "The human capital peace dividend," Journal of Human Resources, 0320-10805R2.

Prete, D. D. And M. Di Maio (2021): "Firms amid conflict: Performance, production inputs, and market competition," .

Pshisva, R. And G. A. Suarez (2006): "Captive markets: The impact of kidnappings on corporate investment in Colombia," .

Restrepo, J., M. Spagat, and J. Vargas (2004): "The dynamics of the columbian civil conflict: A new dataset." Homo Oeconomicus, 21, 396-429.

Richani, N. (1997): "The Political Economy of Violence: The War-System in Colombia." Journal of Interamerican Studies and World Affairs, 39, 37-81.

Rodrik, D. (1999): "Where did all the growth go? External shocks, social conflict, and growth collapses," Journal of Economic Growth, 4, 385-412.

Rozo, S. V. (2018): "Is murder bad for business? Evidence from Colombia," The Review of Economics and Statistics, 100, 769-782.

Sant'Anna, P. H. AND J. Zhao (2020): "Doubly robust difference-in-differences estimators," Journal of Econometrics, 219, 101-122.

Serneels, P. And M. Verpoorten (2015): "The impact of armed conflict on economic performance: Evidence from Rwanda," Journal of Conflict Resolution, 59, 555-592.

Shortland, A., K. Christopoulou, and C. Makatsoris (2013): "War and famine, peace and light? The economic dynamics of conflict in Somalia 1993-2009," Journal of Peace Research, 50, $545-561$.

Singh, P. (2013): "Impact of Terrorism on Investment Decisions of Farmers: Evidence from the Punjab Insurgency," The Journal of Conflict Resolution, 57, 143-168.

Utar, H. (2020): "Firms and labor in times of violence: Evidence from the mexican drug war," . 
Figure 1. Dynamic difference-in-differences



A. Main specification

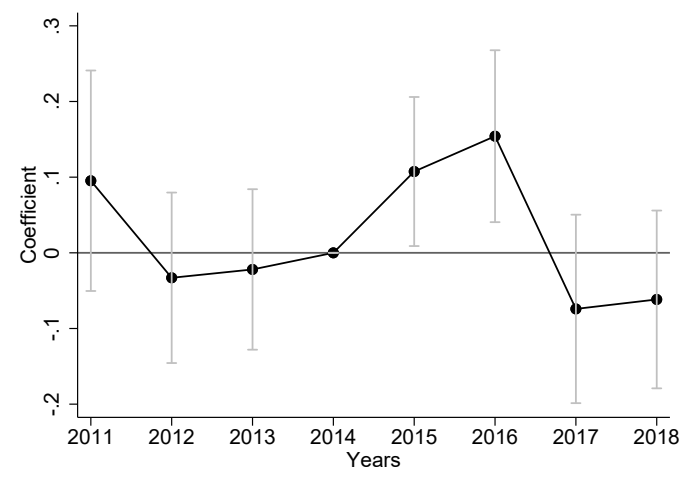

B. Add department-cease FE

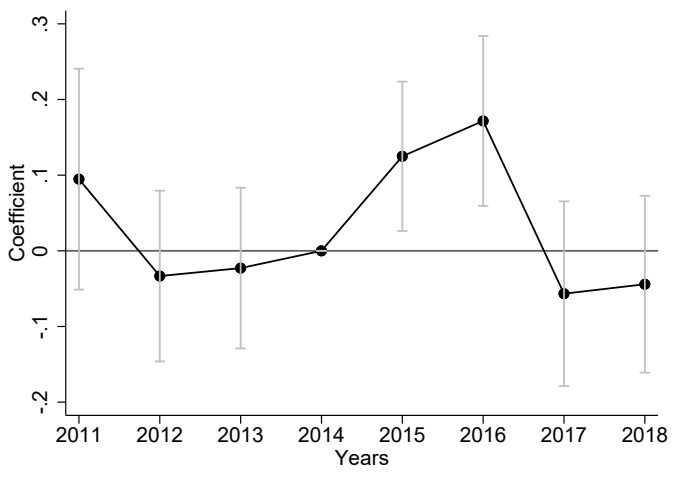

C. Add department-cease FE and controls

Notes: This figure presents the point estimates from equation (4.2). Panel A presents the results with municipality and year fixed effects, Panel B adds department $\times$ ceasefire fixed effects, and Panel $\mathrm{C}$ adds pre-ceasefire controls interacted with the ceasefire dummy. We present the point estimates of the regression and the confidence of interval at the $95 \%$. 
Figure 2. Dynamic difference-in-differences: Firm entry by size of the firm

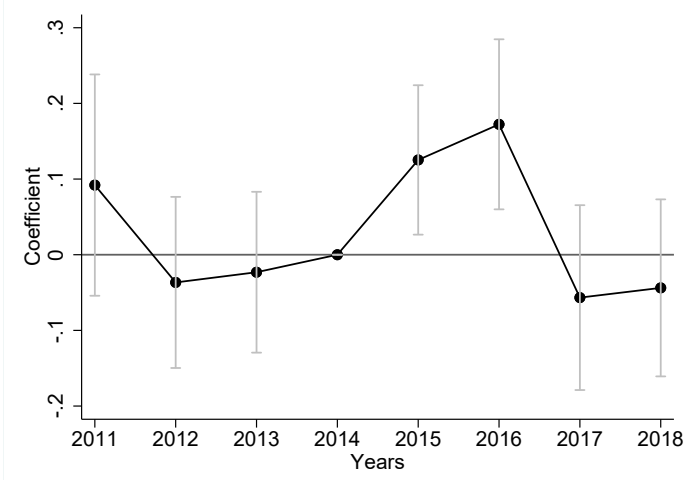

A. Micro

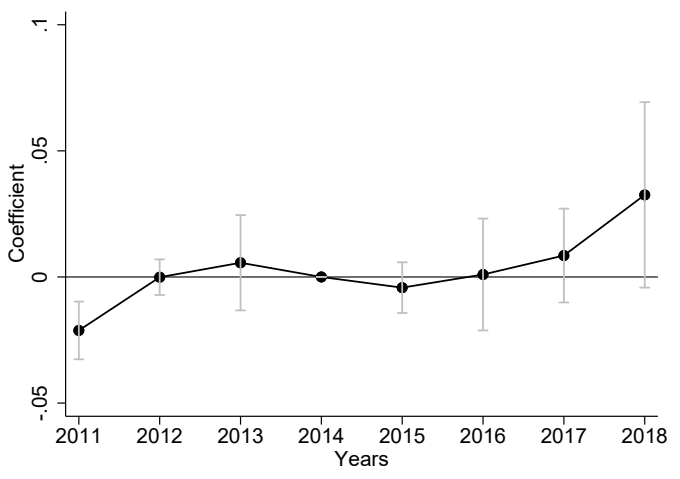

C. Medium



B. Small

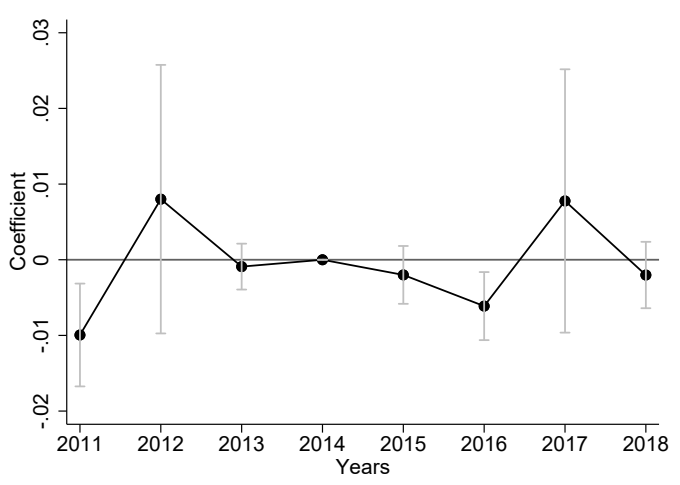

D. Large

Notes: This figure presents the point estimates from equation (4.2) for each firm size. Panel A presents the results for microenterprises, Panel B shows small firms, Panel C shows medium-size firms, and Panel D shows the results for large firms. We present the point estimates of the regression and the confidence of interval at the $95 \%$. 
Figure 3. Dynamic difference-in-differences: Employment by entrants and all firms

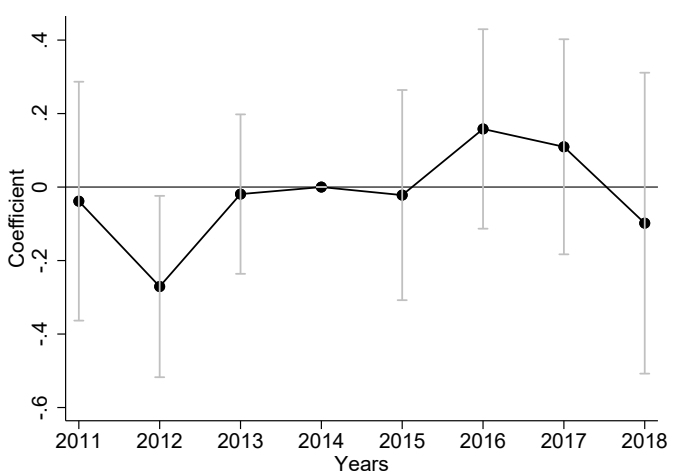

A. Employment for entrants

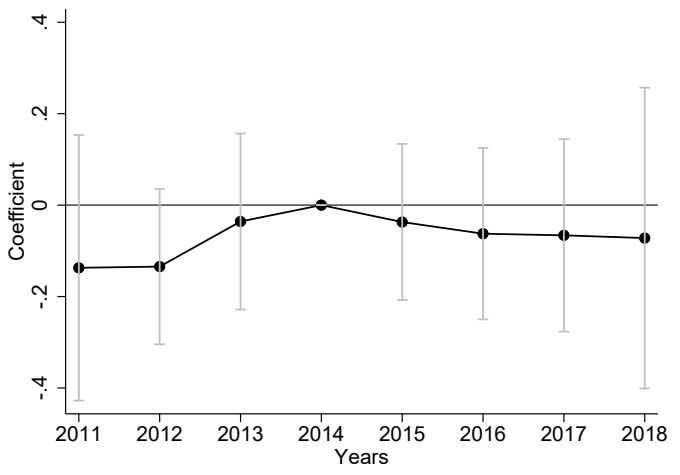

C. Employment for all firms

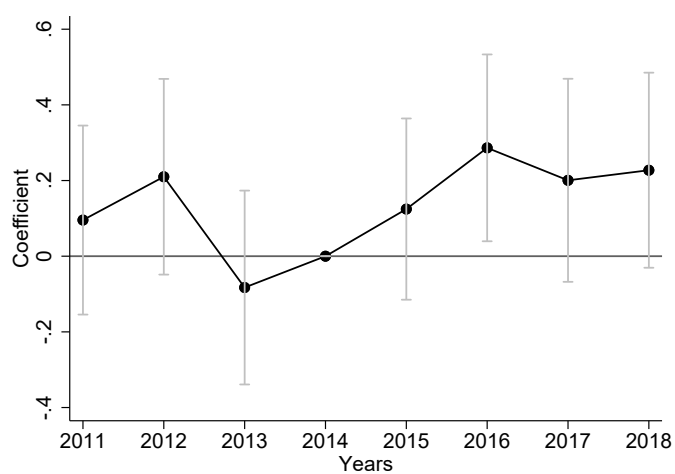

B. Employment-PILA for entrants

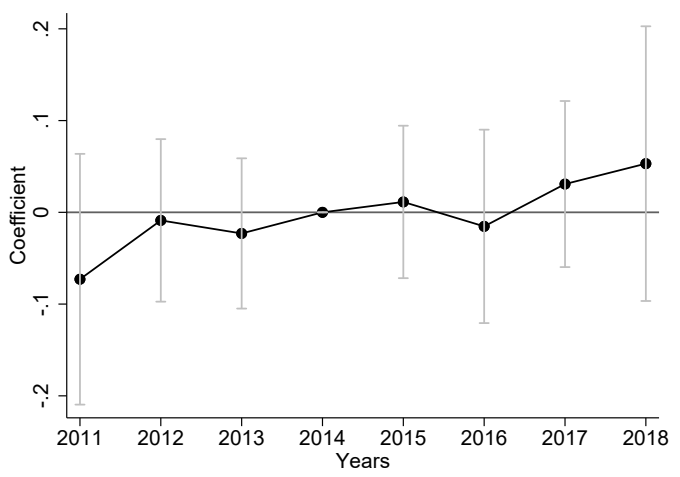

D. Employment-PILA for all firms

Notes: This figure presents the point estimates from equation (4.2) for the employment outcomes. Panel A presents the results of employment reported by the firm, and Panel B for employment reported on PILA for entering firms. Panel C shows those results but for all firms, while Panel D shows the same but employment reported in PILA. We present the point estimates of the regression and the confidence of interval at the $95 \%$. 
Figure 4. Point estimates by sector

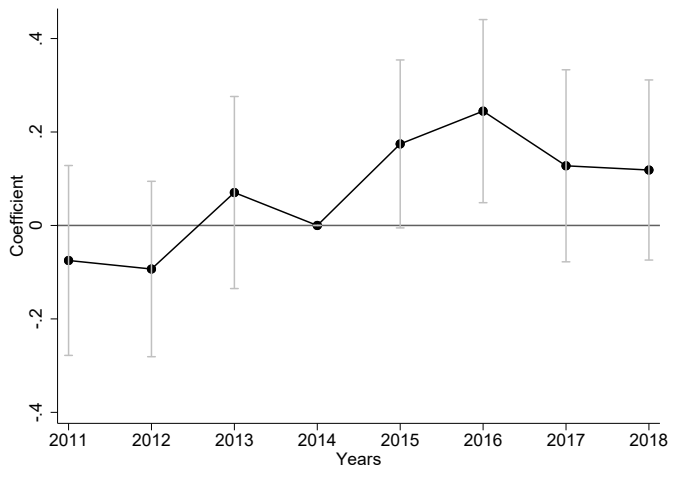

A. Agriculture

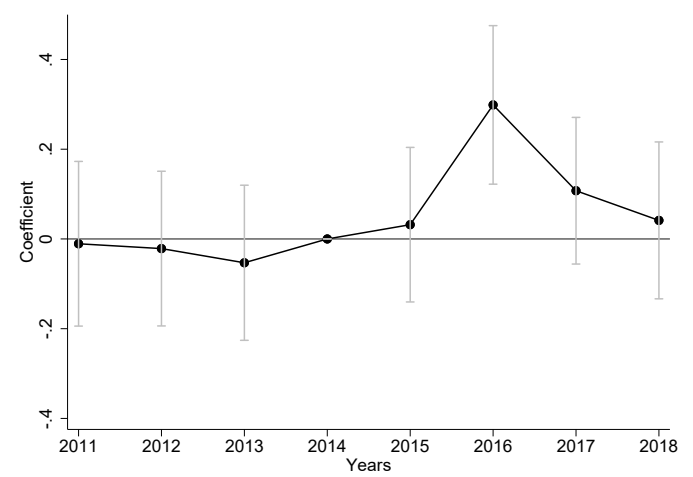

C. Manufacturing



B. Turism

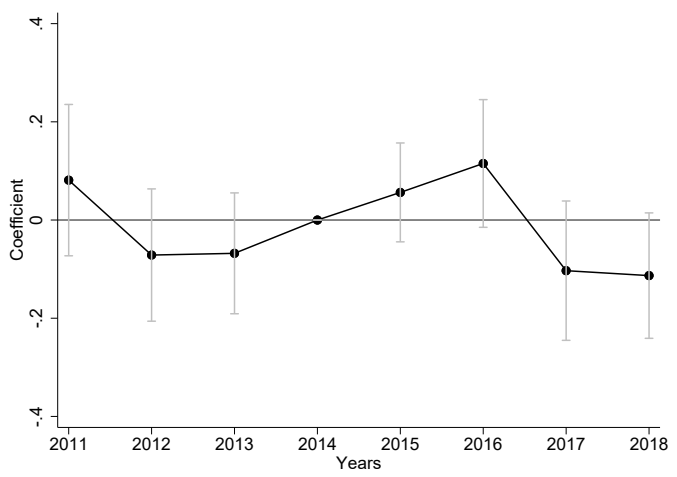

D. Retail

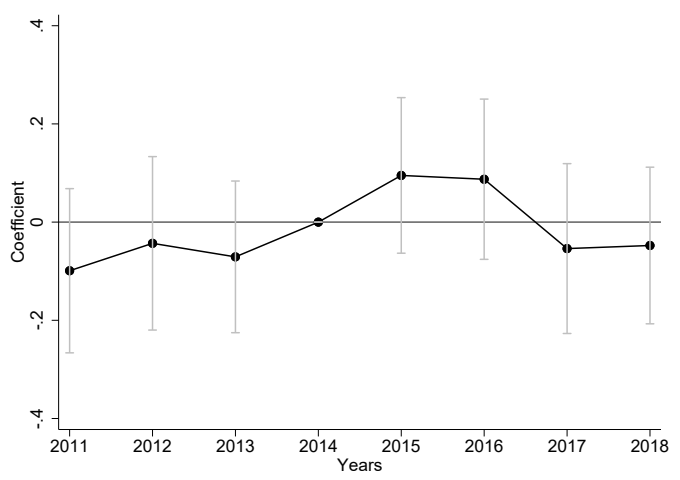

E. Construction

Notes: This figure presents the point estimates from equation (4.2) by sector of the firm. We present the point estimates of the regression and the confidence of interval at the $95 \%$. 
TABLE 1. Summary statistics

\begin{tabular}{|c|c|c|c|c|}
\hline & $\begin{array}{c}(1) \\
\text { Average }\end{array}$ & $\begin{array}{c}(2) \\
\text { Standard } \\
\text { deviation }\end{array}$ & $\begin{array}{c}(3) \\
\text { 90th percentile }\end{array}$ & $\begin{array}{c}(4) \\
\text { 10th percentile }\end{array}$ \\
\hline Number of firms entry & 82.56 & 186.73 & 187.00 & 4.00 \\
\hline HB firm entry & 3.93 & 1.55 & 5.92 & 2.09 \\
\hline FARC & 0.09 & 0.29 & 0.00 & 0.00 \\
\hline Poverty index & 70.30 & 15.72 & 89.35 & 48.23 \\
\hline Log population & 9.46 & 0.97 & 10.70 & 8.25 \\
\hline Share of rurality population & 0.59 & 0.23 & 0.86 & 0.23 \\
\hline Log distance to department capital & 0.04 & 0.91 & 1.07 & -1.07 \\
\hline
\end{tabular}

Notes: This table presents summary statistics for the main variables of interest. 
TABLE 2. Firm entry and ceasefire

The dependent variable is the hyperbolic transformation of firm entry

\begin{tabular}{|c|c|c|c|c|c|c|}
\hline & (1) & $(2)$ & $(3)$ & $(4)$ & $(5)$ & (6) \\
\hline FARC $\times$ Ceasefire & $\begin{array}{c}0.02 \\
(0.04) \\
{[0.52]}\end{array}$ & $\begin{array}{c}0.02 \\
(0.04) \\
{[0.48]}\end{array}$ & $\begin{array}{c}0.04 \\
(0.04) \\
{[0.21]}\end{array}$ & & & \\
\hline \multirow[t]{2}{*}{ (1) FARC $\times$ Years 2015 and 2016} & & & & $\begin{array}{c}0.12^{* * *} \\
(0.04)\end{array}$ & $\begin{array}{c}0.12^{* * *} \\
(0.04)\end{array}$ & $\begin{array}{c}0.14^{* * *} \\
(0.04)\end{array}$ \\
\hline & & & & {$[0.00]$} & {$[0.00]$} & {$[0.00]$} \\
\hline \multirow[t]{3}{*}{ (2) FARC $\times$ Years 2017 and 2018} & & & & -0.08 & -0.08 & -0.06 \\
\hline & & & & $(0.05)$ & $(0.05)$ & $(0.05)$ \\
\hline & & & & {$[0.10]$} & {$[0.06]$} & {$[0.15]$} \\
\hline Observations & 8,736 & 8,736 & 8,736 & 8,736 & 8,736 & 8,736 \\
\hline R-squared & 0.927 & 0.929 & 0.930 & 0.927 & 0.929 & 0.930 \\
\hline Municipality FE & Yes & Yes & Yes & Yes & Yes & Yes \\
\hline Year FE & Yes & Yes & Yes & Yes & Yes & Yes \\
\hline Dept-Cease FE & No & Yes & Yes & No & Yes & Yes \\
\hline Controls FE & No & No & Yes & No & No & Yes \\
\hline Municipalities & 1092 & 1092 & 1092 & 1092 & 1092 & 1092 \\
\hline Mean DV & 3.871 & 3.871 & 3.871 & 3.871 & 3.871 & 3.871 \\
\hline SD DV & 1.569 & 1.569 & 1.569 & 1.569 & 1.569 & 1.569 \\
\hline $\mathrm{p}$-values diff between (1) and (2) & & & & 0.00 & 0.00 & 0.00 \\
\hline
\end{tabular}

Notes: This table presents the results from the main specification in equation (4.1). FARC is defined as a dummy that takes the value one if the municipality experiences any FARC attacks for the period 2011 to 2014. Ceasefire is a dummy that takes the value one for the period after 2014. Years 2015 and 2016 is a dummy that takes the value one for years 2015 and 2016, while Years 2017 and 2018 is a dummy that takes the value one for the years 2017 and 2018 . Columns 2 and 5 add department $\times$ ceasefire fixed effects. Columns 3 and 6 add predetermined municipal controls interacted with the ceasefire dummy. This controls include logarithm of the population in 2010, share of rural population, poverty index, and distance to the department capital. In addition, in columns 4, 5 and 6 , we show the p-values of the difference between the coefficients of the interaction between FARC and the early and later years. Robust standard errors are clustered at the municipality level and presented in parenthesis. In square brackets, we present the p-values for standard errors control for spatial and first-order time correlation (see Conley, 1999, Conley, 2016). We allow spatial correlation to extend to up to $416 \mathrm{~km}$ from each municipality's centroid, which is the average distance from one municipality to all the rest. ${ }^{*}$ is significant at the $10 \%$ level, ${ }^{* *}$ is significant at the $5 \%$ level, *** is significant at the $1 \%$ level. 










TABLE 5. Firm entry's employment and ceasefire

The dependent variable is the hyperbolic transformation of number of employees

\begin{tabular}{|c|c|c|c|c|c|c|}
\hline & (1) & $(2)$ & (3) & (4) & (5) & (6) \\
\hline \multicolumn{7}{|l|}{ Panel A: Self-reported employment } \\
\hline FARC $\times$ Years 2015 and 2016 & & & & $\begin{array}{c}0.27^{* *} \\
(0.11)\end{array}$ & $\begin{array}{l}0.19^{*} \\
(0.11)\end{array}$ & $\begin{array}{c}0.15 \\
(0.11)\end{array}$ \\
\hline FARC $\times$ Years 2017 and 2018 & & & & $\begin{array}{c}0.21 \\
(0.16)\end{array}$ & $\begin{array}{c}0.13 \\
(0.13)\end{array}$ & $\begin{array}{c}0.09 \\
(0.13)\end{array}$ \\
\hline FARC $\times$ Ceasefire & $\begin{array}{c}0.24^{* *} \\
(0.12)\end{array}$ & $\begin{array}{c}0.16^{*} \\
(0.10)\end{array}$ & $\begin{array}{c}0.12 \\
(0.10)\end{array}$ & & & \\
\hline \multicolumn{7}{|l|}{ Panel B: Formal employment } \\
\hline FARC $\times$ Years 2015 and 2016 & & & & $\begin{array}{c}0.18^{* *} \\
(0.07)\end{array}$ & $\begin{array}{c}0.11 \\
(0.08)\end{array}$ & $\begin{array}{c}0.15^{* *} \\
(0.07)\end{array}$ \\
\hline FARC $\times$ Years 2017 and 2018 & & & & $\begin{array}{c}0.19^{* *} \\
(0.08)\end{array}$ & $\begin{array}{c}0.12 \\
(0.09)\end{array}$ & $\begin{array}{l}0.16^{*} \\
(0.09)\end{array}$ \\
\hline FARC $\times$ Ceasefire & $\begin{array}{c}0.18^{* * *} \\
(0.07)\end{array}$ & $\begin{array}{c}0.11 \\
(0.07)\end{array}$ & $\begin{array}{c}0.15^{* *} \\
(0.07)\end{array}$ & & & \\
\hline Observations & 8,736 & 8,736 & 8,736 & 8,736 & 8,736 & 8,736 \\
\hline R-squared (Panel A) & 0.760 & 0.777 & 0.778 & 0.760 & 0.777 & 0.778 \\
\hline R-squared (Panel B) & 0.835 & 0.836 & 0.836 & 0.835 & 0.836 & 0.836 \\
\hline Municipality FE & Yes & Yes & Yes & Yes & Yes & Yes \\
\hline Year FE & Yes & Yes & Yes & Yes & Yes & Yes \\
\hline Dept-Cease FE & No & Yes & Yes & No & Yes & Yes \\
\hline Controls FE & No & No & Yes & No & No & Yes \\
\hline Municipalities & 1092 & 1092 & 1092 & 1092 & 1092 & 1092 \\
\hline Mean DV (Panel A) & 3.283 & 3.283 & 3.283 & 3.283 & 3.283 & 3.283 \\
\hline Mean DV (Panel B) & 2.591 & 2.591 & 2.591 & 2.591 & 2.591 & 2.591 \\
\hline SD DV (Panel A) & 2.077 & 2.077 & 2.077 & 2.077 & 2.077 & 2.077 \\
\hline SD DV (Panel B) & 1.896 & 1.896 & 1.896 & 1.896 & 1.896 & 1.896 \\
\hline p-values diff between (1) and (2) (Panel A) & & & & 0.660 & 0.650 & 0.650 \\
\hline p-values diff between (1) and (2) (Panel B) & & & & 0.910 & 0.900 & 0.910 \\
\hline
\end{tabular}

Notes: This table presents the results from the main specification in equation (4.1) for employment reported by the firm (Panel A) and for formal employment reported in PILA (Panel B). FARC is defined as a dummy that takes the value one if the municipality experiences any FARC attacks for the period 2011 to 2014. Ceasefire is a dummy that takes the value one for the period after 2014. Years 2015 and 2016 is a dummy that takes the value one for years 2015 and 2016, while Years 2017 and 2018 is a dummy that takes the value one for the years 2017 and 2018. Columns 2 and 5 add department $\times$ ceasefire fixed effects. Columns 3 and 6 add predetermined municipal controls interacted with the ceasefire dummy. This controls include logarithm of the population in 2010, share of rural population, poverty index, and distance to the department capital. In addition, in columns 4, 5 and 6 , we show the p-values of the difference between the coefficients of the interaction between FARC and the early and later years. Robust standard errors are clustered at the municipality level and presented in parenthesis. $*$ is significant at the $10 \%$ level, ${ }^{* *}$ is significant at the $5 \%$ level, ${ }^{* * *}$ is significant at the $1 \%$ level. 


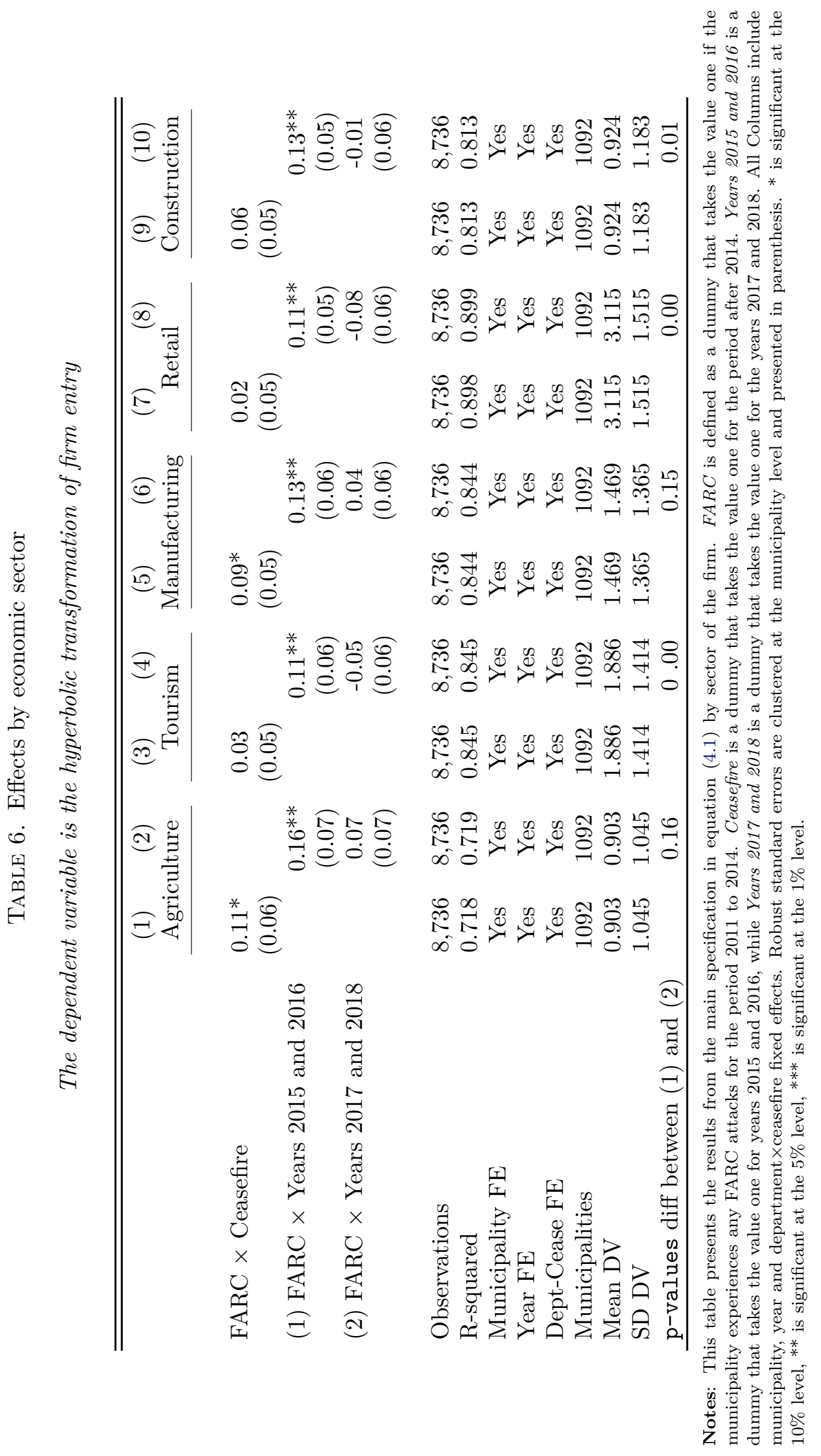


TABLE 7. Heterogeneous effects: Government programs

\begin{tabular}{|c|c|c|c|c|}
\hline & (1) & $(2)$ & (3) & $(4)$ \\
\hline & \multicolumn{2}{|c|}{ Tax benefits } & \multicolumn{2}{|c|}{ PDET } \\
\hline FARC $\times$ Years 2017 and $2018 \times \mathrm{Z}$ & & $\begin{array}{c}0.26^{* * *} \\
(0.06)\end{array}$ & & $\begin{array}{c}0.21^{* *} \\
(0.08)\end{array}$ \\
\hline FARC $\times$ Years 2015 and 2016 & $\begin{array}{c}0.11^{* * *} \\
(0.04)\end{array}$ & $\begin{array}{c}0.11^{* * *} \\
(0.04)\end{array}$ & $\begin{array}{c}0.11^{* * * *} \\
(0.04)\end{array}$ & $\begin{array}{c}0.11^{* * *} \\
(0.04)\end{array}$ \\
\hline FARC $\times$ Years 2017 and 2018 & $\begin{array}{l}-0.01 \\
(0.05)\end{array}$ & $\begin{array}{c}-0.24^{* * *} \\
(0.05)\end{array}$ & $\begin{array}{l}-0.00 \\
(0.05)\end{array}$ & $\begin{array}{l}-0.12^{*} \\
(0.07)\end{array}$ \\
\hline Years 2017 and $2018 \times \mathrm{Z}$ & $\begin{array}{c}-0.12^{* * *} \\
(0.03)\end{array}$ & $\begin{array}{c}-0.13^{* * *} \\
(0.03)\end{array}$ & $\begin{array}{c}-0.14^{* * *} \\
(0.04)\end{array}$ & $\begin{array}{c}-0.18^{* * *} \\
(0.04)\end{array}$ \\
\hline Observations & 8736 & 8736 & 8736 & 8736 \\
\hline R-squared & 0.929 & 0.929 & 0.929 & 0.929 \\
\hline Municipality FE & Yes & Yes & Yes & Yes \\
\hline Year FE & Yes & Yes & Yes & Yes \\
\hline Dept-Cease FE & Yes & Yes & Yes & Yes \\
\hline Municipalities & 1092 & 1092 & 1092 & 1092 \\
\hline Mean DV & 3.87 & 3.87 & 3.87 & 3.87 \\
\hline SD DV & 1.57 & 1.57 & 1.57 & 1.57 \\
\hline
\end{tabular}

Notes: This table presents the results from the specification in equation (4.3). FARC is defined as a dummy that takes the value one if the municipality experiences any FARC attacks for the period 2011 to 2014 . Years 2015 and 2016 is a dummy that takes the value one for years 2015 and 2016, while Years 2017 and 2018 is a dummy that takes the value one for the years 2017 and 2018. $Z$ is a dummy that takes the value one if the municipality benefits from special post-conflict programs. In columns 1 and $2, Z$ is a dummy that takes value one if the municipality has tax benefits or not, while in columns 3 and $4, Z$ is a dummy variable that takes value one if the municipality benefits from the PDETs. Robust standard errors are clustered at the municipality level and presented in parenthesis. ${ }^{*}$ is significant at the $10 \%$ level, ${ }^{* *}$ is significant at the $5 \%$ level, ${ }^{* * *}$ is significant at the $1 \%$ level. 
TABLE 8. Heterogeneous effects: Other municipality characteristics

\begin{tabular}{|c|c|c|c|c|}
\hline & $\begin{array}{c}\text { (1) } \\
\text { Conflict } \\
\text { intensity }\end{array}$ & $\begin{array}{c}(2) \\
\text { Total } \\
\text { transfers }\end{array}$ & $\begin{array}{c}\text { (3) } \\
\text { Population } \\
\text { density }\end{array}$ & $\begin{array}{c}(4) \\
\text { Distance to } \\
\text { other near } \\
\text { markets }\end{array}$ \\
\hline FARC $\times$ Years 2015 and $2016 \times \mathrm{Z}$ & $\begin{array}{c}0.15^{* *} \\
(0.06)\end{array}$ & $\begin{array}{c}0.06^{* *} \\
(0.03)\end{array}$ & $\begin{array}{l}0.14^{*} \\
(0.07)\end{array}$ & $\begin{array}{l}-0.08^{*} \\
(0.04)\end{array}$ \\
\hline FARC $\times$ Years 2017 and $2018 \times \mathrm{Z}$ & $\begin{array}{l}0.15^{*} \\
(0.08)\end{array}$ & $\begin{array}{l}-0.05 \\
(0.04)\end{array}$ & $\begin{array}{c}0.11 \\
(0.09)\end{array}$ & $\begin{array}{c}-0.11^{* *} \\
(0.06)\end{array}$ \\
\hline FARC $\times$ Years 2015 and 2016 & $\begin{array}{c}0.04 \\
(0.04)\end{array}$ & $\begin{array}{c}0.12^{* * *} \\
(0.04)\end{array}$ & $\begin{array}{c}0.04 \\
(0.06)\end{array}$ & $\begin{array}{c}0.12^{* * *} \\
(0.04)\end{array}$ \\
\hline FARC $\times$ Years 2017 and 2018 & $\begin{array}{c}-0.15^{* *} \\
(0.06)\end{array}$ & $\begin{array}{l}-0.08 \\
(0.05)\end{array}$ & $\begin{array}{l}-0.11 \\
(0.07)\end{array}$ & $\begin{array}{l}-0.05 \\
(0.05)\end{array}$ \\
\hline Years 2015 and $2016 \times \mathrm{Z}$ & & $\begin{array}{c}-0.03^{* *} \\
(0.01)\end{array}$ & $\begin{array}{l}-0.01 \\
(0.04)\end{array}$ & $\begin{array}{c}0.03 \\
(0.03)\end{array}$ \\
\hline Years 2017 and $2018 \times \mathrm{Z}$ & & $\begin{array}{l}0.05^{*} \\
(0.03)\end{array}$ & $\begin{array}{c}0.13^{* * *} \\
(0.05)\end{array}$ & $\begin{array}{l}-0.03 \\
(0.03)\end{array}$ \\
\hline Observations & 8,736 & 8,736 & 8,736 & 8,736 \\
\hline R-squared & 0.929 & 0.929 & 0.929 & 0.929 \\
\hline Municipality FE & Yes & Yes & Yes & Yes \\
\hline Year FE & Yes & Yes & Yes & Yes \\
\hline Dept-Cease FE & Yes & Yes & Yes & Yes \\
\hline Municipalities & 1092 & 1092 & 1092 & 1092 \\
\hline Mean DV & 3.871 & 3.871 & 3.871 & 3.871 \\
\hline SD DV & 1.569 & 1.569 & 1.569 & 1.569 \\
\hline
\end{tabular}

Notes: This table presents the results from the specification in equation (4.3). FARC is defined as a dummy that takes the value one if the municipality experiences any FARC attacks for the period 2011 to 2014 . Years 2015 and 2016 is a dummy that takes the value one for years 2015 and 2016, while Years 2017 and 2018 is a dummy that takes the value one for the years 2017 and 2018. $Z$ is a characteristic of the municipality measured before the ceasefire. In column $1, Z$ is a dummy variable that takes values one if the municipality is above the median of conflict intensity. In column $2, Z$ is the average transfer from another government level between 2011 and 2014. In column 3, $Z$ is a dummy that takes value one if the municipality had the population density above the lower quartile in 2014. Finally, in column $4, Z$ is the standardized distance of the municipality to a nearby wholesale food market. Robust standard errors are clustered at the municipality level and presented in parenthesis. $*$ is significant at the $10 \%$ level, ${ }^{* *}$ is significant at the $5 \%$ level, ${ }^{* * *}$ is significant at the $1 \%$ level. 


\section{APPENDIX}

Figure A.1. Exclude one FARC municipality and one department at the time

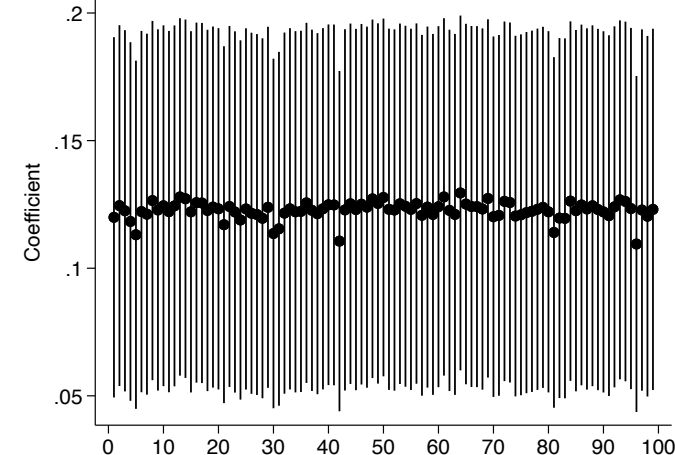

A. Excl FARC: Years 2015 and 2016

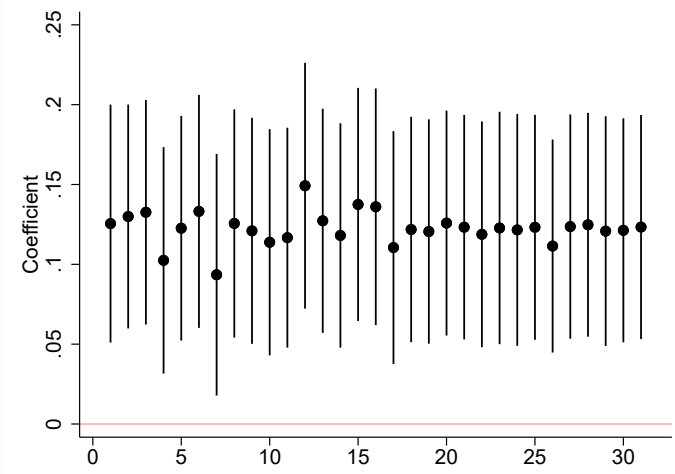

C. Excl Dept: Years 2015 and 2016

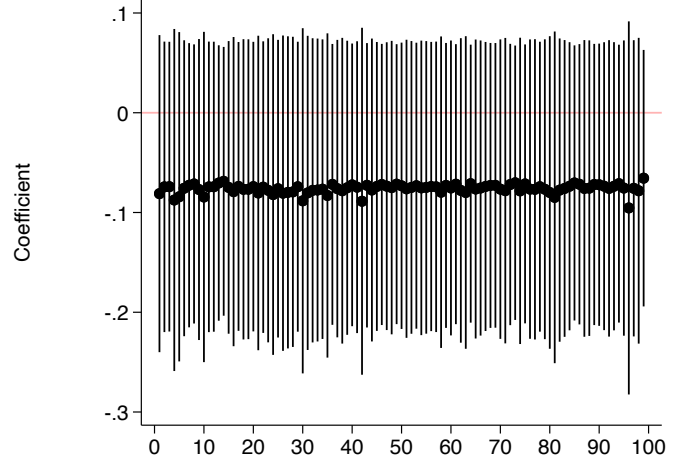

B. Excl FARC: Years 2017 and 2018

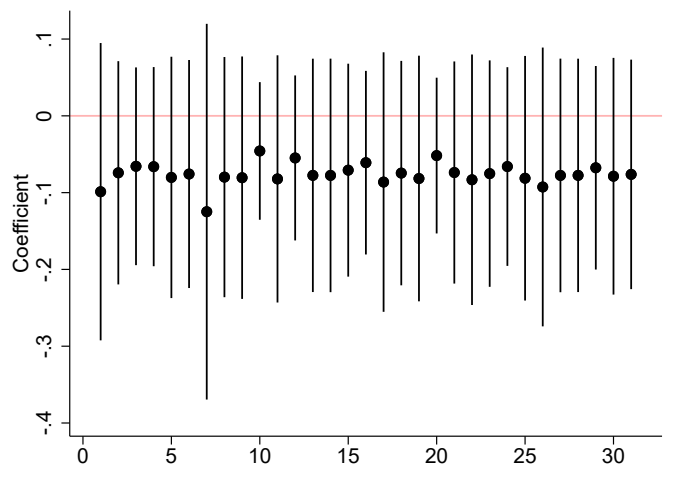

D. Excl Dept: Years 2017 and 2018

Notes: This figure presents the results our main specification. In Panels A and B we drop one of the FARC affected municipalities at the time, while Panels $\mathrm{C}$ and D remove one department at the time. Panels A and $\mathrm{C}$ show the results for the interaction between FARC and the dummy for years 2015 and 2016, while Panels B and D present the results for the interaction between FARC and the dummy for years 2017 and 2018. 


\section{FiguRE A.2. Distribution of placebo treatments}

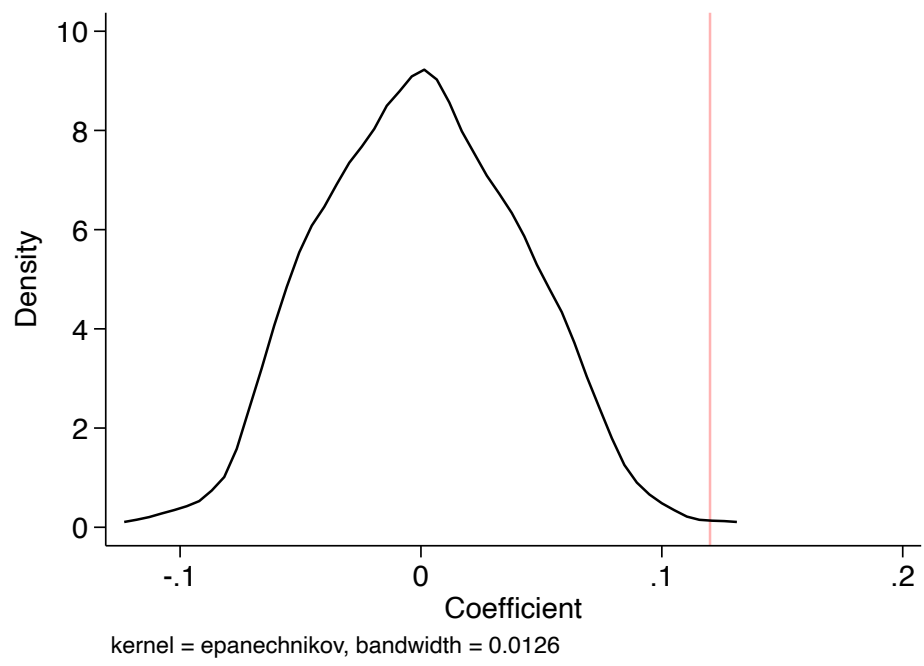

A. Years 2015 and 2016

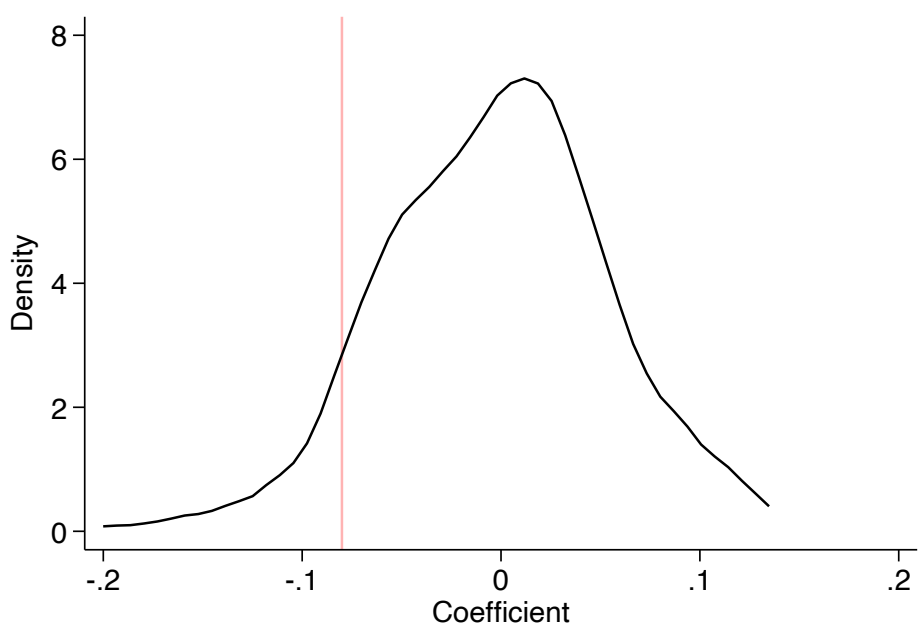

kernel $=$ epanechnikov, bandwidth $=0.0169$

B. Years 2017 and 2018

Notes: This figure presents the distribution of placebo treatments. We randomize the assignment of a municipality to have FARC presence before the ceasefire based on the number of municipalities exposed (99). We run the regressions using the specification from Column 5 in Table 2. Panel A shows the results for the interaction between the placebo FARC and the dummy for years 2015 and 2016, while Panel B presents the results for the interaction between the placebo FARC and the dummy for years 2017 and 2018. The red line presents the coefficient of Column 5 of Table 2. In Panel A the p-values, i.e. the number of cases where the placebo effect shows a larger decrease in firm creation after the ceasefire, is 0 , while in Panel B is 0.07 . 
TABLE A.1. Difference by exposure to FARC's violence

\begin{tabular}{lccc}
\hline \hline & $(1)$ & & $(2)$ \\
& Avg without & & FARC Presence \\
& FARC presence & & \\
\cline { 2 - 3 } HB firm entry & 3.89 & & $0.48^{* * *}$ \\
& $(1.56)$ & & $(0.08)$ \\
Poverty index & 69.53 & & $8.51^{* * *}$ \\
& $(15.76)$ & & $(0.70)$ \\
Log population & 9.41 & & $0.58^{* * *}$ \\
& $(0.96)$ & & $(0.04)$ \\
Share of rurality population & 0.58 & & $0.05^{* * *}$ \\
& $(0.23)$ & & $(0.01)$ \\
Log distance to department capital & 0.03 & & $0.14^{* * *}$ \\
& $(0.91)$ & $(0.05)$ \\
\hline \hline
\end{tabular}

Notes: This table presents univariate regressions based on municipality characteristics before the ceasefire. Column 1 presents the average of each variable before the ceasefire for municipalities non-exposed to FARC violence. Column 2 presents the estimated coefficient and standard errors from univariate regressions for the discrete treatment. ${ }^{* * *} \mathrm{p}<0.01,{ }^{* *} \mathrm{p}<0.05, *$ $\mathrm{p}<0.1$. 